\title{
ATTRIBUTES OF IMPROVING SERVICE QUALITY ON CONSUMER SATISFACTION WITH SERVQUAL APPROACH
}

\author{
Poniman $^{1}$, Yitno Utomo ${ }^{2}$ \\ ${ }^{1}$ Engineering Faculty, Muhammadiyah University of Surabaya \\ ${ }^{2}$ Industrial Engineering Department, Faculty of Industrial Technology, University of PGRI Adi Buana Surabaya \\ email: poniman@ft.um-surabaya.ac.id
}

\begin{abstract}
This research aim to find out service quality attributes that can increase customer satisfaction. One service company is $\mathrm{CV}$. Nirwana which is engaged in the sale and service of office equipment maintenance. winning business competition company must create a strategy that can improve the quality of service to consumers. Themethod used in this study is the ServQual Method which includes 5 main dimensions, namely Tangibles, Reliability, Responsiveness, Assurance and Emphaty. The ServQual method is a tool used to measure the services or products of the quality of services received by consumers.

Based on the level of service quality there is a negative attribute value on the variable on the dimensions of reliability and responsiveness. Negative values indicate that the quality of service is not quality and consumers do not feel satisfaction with the services provided by the company. Positive values are found in the tangibles, assurance and empathy variables which show that the service provided can be said to be a surprise and consumers feel satisfaction with the service. Therefore, the company is expected to be able to improve the quality of services that are of negative value, namely engine cleanliness after repairs, speed and timeliness in providing services, seriousness and reliability of technicians in completing repairs, availability of historical data / recording systems that are good at service, providing service services in accordance with promise, Alertness in providing assistance to consumers if experiencing difficulties Provide a good explanation of repairs, costs and estimated time to consumers, the ability of service advisors in diagnosing customer problems / complaints.
\end{abstract}

Keywords: Service Company, Consumer Satisfaction and ServQual.

\section{INTRODUCTION}

Consumer satisfaction is the main goal in service company services. companies must immediately make a strategy and careful planning in the face of competition in the present and the future by referring to "customer oriented" that is by studying and understanding everything related to consumers/ customers. Customers are the focal point of every business (cakrabarty \& tan in Hasim Hanafie, 2011). Competition Service companies currently experiencing very tight competition, this can be seen from the increasing number of service companies, so companies must immediately create or design appropriate strategies and methods in dealing with these problems. One method that companies can do is to improve services to consumers so that consumers can feel satisfaction over the services provided.

$\mathrm{CV}$. Nirwana is a company engaged in the field of goods procurement services and computer repair services. Based on company data from 2015 to 2018, the number of consumers has decreased, therefore the company must do concrete steps so that the company can again win the competition. Data on the number of consumers who use CV. Nirwana services can be seen in table 1 below:

Based on the table above shows that there is a decrease in the number of consumers of users of company services CV. Nirvana from 2015 to 2018. This can cause profits from the company to decrease. So that it needs to be evaluated, to find what causes rather than a 
decrease in the number of consumers who use care services in the CV. Nirvana.

The purpose of this study is to determine the attributes in the five dimensions of service quality (tangibles, reliability, responsiveness, assurance and empathy) that have an effect on increasing consumer satisfaction with services, To determine priority attributes that can increase customer satisfaction with services and Applying the servqual method in increasing customer satisfaction with services.

Table 1. Sales and repair data for the year 2015 -2018

\begin{tabular}{lcccc}
\hline Type of Service & year & year & year & year \\
& 2015 & 2016 & 2017 & 2018 \\
\hline Purchase of goods & 80 & 83 & 90 & 88 \\
Repair service & 95 & 102 & 89 & 80 \\
Amoaunt & 175 & 185 & 179 & 168 \\
\hline
\end{tabular}

Consumer satisfaction is a function of the closeness between what is the expectation of consumers with the perceived product performance. So satisfaction is the difference from the perceived results, so customer satisfaction is an estimate or customer belief about what consumers will receive if they buy or consume a product or service, while the perceived performance is the customer's perception of what consumers receive after consumers consume the product or services that have been conceptually purchased (Kotler, in 2016). One strategy that can improve competitiveness is by improving service quality. Kotler, (2012), states that customer satisfaction is a post-purchase evaluation with a variety of alternatives chosen by consumers at least able to provide the same results or exceed consumer expectations. If consumers achieve satisfaction with the services of the company it can affect the intention of consumer behavior to buy goods or services offered by the company

The intention of consumers to purchase goods or services is influenced by the quality of service provided by the company and customer satisfaction. The company seeks to improve good service, in products or services to consumers consistently and excellent service quality so that consumers can feel the satisfaction of an item or service it receives. Whereas Service is an activity which has several intangible elements. The difference between services and manufacturing from the point of view of production and consumption will distinguish the behavior of services in their operations. And can be seen in table 2 .

Service is a performance or action from a service provider that can provide consumer benefits to realize the changes desired by consumers. While FandyTjiptono, (2012) there are four characteristic characteristics of services, namely Intangibilities, namely services that cannot be felt, seen, smelled, heard, touched or consumed, Inseparability, namely services that are generally sold first then just produced and consumed together. Variability, which is non standardized output where there are variations in form, quality and service, but depending on who, where and when services are produced and are easily are commodities that do not last long and cannot be stored with problems that exist when demand fluctuates 
Table 2. Difference Between Service and Manufacturing Industries

\begin{tabular}{cc}
\hline Manufactur & Services \\
\hline The product can be touched & The product cannot be touched
\end{tabular}

Ownership can be transferred at the time of Ownership in general is not transferred purchase

Products can be resold

Products can be demonstrated before buying Products can be stored as inventory

The product precedes consumption

Production and consumption activities can be separated in the location of activities

Product can be moved

The seller produces

\section{Allows indirect contact between company and} customers

Products can be exported

Businesses are organized by function, with separate sales and production

Source : Arman Hakim Nasution ,2006

Based on the service triangle that service priorities focus on the customer. Because the customer is the main element of the service process. The application of these services must be carried out starting from operational employees as well as all employees in the company or a company commitment. The service triangle can be used to diagnose service problems, to determine the cause of poor and useful services to design service systems and to solve service problems, (Arman Hakim Nasution, in poniman 2016).

Servqual is a tool designed to measure the quality of services received by consumers (Chen, et al, 2009), but it can also be used to analyze a cause of problems related to service and analyze differences in perceptions and expectations of services provided by companies to consumer. While the quality of service is the expected level of excellence and control over the level of excellence to meet consumer desires. The ideal service quality is the service received as expected and is perceived as good and satisfying consumers or exceeding service expectations received by
It is impossible to repeat it

Product does not exist before purchase

The product cannot be saved

Production and consumption occur simultaneously

Production and consumption activities must occur in the same location

Product cannot be moved

Buyers take part directly in the production process and can actually do part of the production

Most need direct contact

Services generally cannot be exported, but service systems

Sales and production cannot be separated functionally service consumers. While the tools used to measure service quality can be in the form of questionnaires distributed to consumers of service users Zeithaml, (2013). Stating that there are five dimensions of service quality (SERVQUAL) as follows:

a. Physical Proof (Tangible)

Physical facilities, equipment and

infrastructure that can and must be in the service process.

b. Reliability

The ability to provide services accurately, reliably, on time, according to the promised schedule and without making mistakes

c. Responsiveness

The ability of all employees to help and provide services to the needs of consumers.

d. Assurance

Knowledge, ability, friendly, polite and trustworthy nature of contact personnel and consumers feel free from danger and risk.

e. Empathy (Empathy) Includes contact personnel and or companies to understand the needs and 
difficulties of consumers, as well as the ease of communication or relationships

\section{METHOD}

The design of this study is an experimental research design. Experimental design is an experimental design with every step of the action defined, so that information related to or needed an issue to be studied can be collected factually (Juliansyah Noor, 2011). Experimentation is a way to find a causal relationship (causal relationship) between two factors that are intentionally caused by researchers by eliminating or reducing or eliminating other factors that interfere (Arikunto, 2010). The dependent variable in this study is consumers' satisfaction towards services while the independent variables are:
a. Tangibles
b. Reliability
c. Responsiveness
d. Assurance
e. Emphaty

While the analysis used using the Servqual Method is a method that can give an explanation of the performance attributes to the discovery of the gap score. While the results of this gap are calculated by using the difference in perception of satisfaction or reality of service with the expectations or levels of consumer interest. Calculation of gap scores using the equation below

Perseption - Hope $=$ Gap Or P - H = Gap

\section{RESULTS AND DISCUSSION}

General Description The object of the study was conducted to analyze the services provided by the company to customers / consumers CV. Nirvana. The data collected by researchers are all consumers of CV. Nirvana who uses the company services. In general the object of research starts from private companies, government, factories and companies.

The first step in conducting this research is by determining the quality dimension attributes that can increase customer satisfaction. One of the data retrieval by making and distributing questionnaires to consumers, where the manufacture of this questionnaire was carried out in consultation with the company. the aim is to find out the attributes of consumer interest and satisfaction with the services of $\mathrm{CV}$ Nirwana.After collecting respondents' data the validity and reliability tests are carried out. An instrument is said to be valid if it is able to measure what is desired and can reveal data from the variables studied appropriately. The high or low validity of this instrument shows the extent to which the data is collected and does not deviate from the description of the intended variable.

The technique used for this validity test is the product moment correlation technique. Items are declared valid if the correlation coefficient is calculated $\geq$ the correlation coefficient of the table or $\mathrm{r}$ arithmetic $\geq$ rtable. The variable validity test results show that the research instrument used can be said to be valid. This is shown from the results of the correlation coefficient test of each attribute variable has a value of more than a critical value of 0.3 or $r h$ rtable. Meanwhile, based on the results of the calculation of reliability, of the six variables above have acceptable reliability with reliability levels between 0.946 - 0.983 , or are above 0.6., So it can be said to be reliable. Statement that the instrument has a high reliability if the reliability coefficient value obtained>0.60 ServQual Analysis is a method used to determine the criteria between the perception gap and expectations of consumers. The servqual method consists of two parts, namely assessment and weighting Assessment is done by distributing questionnaires by means of a participant giving a weight (contant sum rating scale) for the five dimensions. While the difference between perception and expectations is called a gap or service quality gap which is formulated as follows: 
Table3. Value gap between expectations and perceptions of care services CV. Nirwana

\begin{tabular}{|c|c|c|c|c|}
\hline \multirow{2}{*}{ No } & \multirow[b]{2}{*}{ Statement } & \multicolumn{2}{|c|}{ Average } & \multirow{2}{*}{ Gap } \\
\hline & & Satisfaction & Hope & \\
\hline 1 & Having physical facilities & 3,58 & 2,44 & 1,14 \\
\hline 2 & Spearpart availability. & 3,77 & 3,29 & 0,48 \\
\hline 3 & Neat staff and employee appearances. & 3,60 & 3,40 & 0,2 \\
\hline 4 & Engine cleanliness after repair. & 3,42 & 3,64 & $-0,22$ \\
\hline 5 & Speed and timeliness in providing services & 2,58 & 4,03 & $-1,45$ \\
\hline 6 & $\begin{array}{l}\text { The seriousness and reliability of the technician in } \\
\text { completing repairs. }\end{array}$ & 2,31 & 3,74 & $-1,43$ \\
\hline 7 & $\begin{array}{l}\text { Availability of good historical data / recording } \\
\text { system at the time of service. }\end{array}$ & 3,58 & 3,85 & $-0,27$ \\
\hline 8 & Providing services in accordance with the promise & 2,42 & 3,98 & $-1,56$ \\
\hline 9 & $\begin{array}{l}\text { Give consumers a good explanation of repairs, costs } \\
\text { and estimated time. }\end{array}$ & 2,27 & 3,86 & $-1,59$ \\
\hline 10 & $\begin{array}{l}\text { Alertness in providing assistance to consumers if } \\
\text { experiencing difficulties. }\end{array}$ & 2,28 & 3,95 & $-1,67$ \\
\hline 11 & $\begin{array}{l}\text { The ability of service advisors in diagnosing } \\
\text { customer problems / complaints. }\end{array}$ & 3,34 & 3,53 & $-0,19$ \\
\hline 12 & Staff politeness and friendliness & 3,87 & 3,50 & 0,37 \\
\hline 13 & Provide a warranty. & 3,99 & 3,49 & 0,5 \\
\hline 14 & Carrying out controls with customers is done repairs. & 3,38 & 2,76 & 0,62 \\
\hline 15 & Follow up after repairs. & 3,53 & 2,71 & 0,82 \\
\hline 16 & Provide input and explanation to customers. & 3,85 & 3.13 & 0,72 \\
\hline 17 & Provide accurate information & 3,53 & 2,80 & 0,73 \\
\hline
\end{tabular}

Based on the table above there are negative attribute values on the variables on the dimensions of reliability and responsiveness. negative values indicate that the quality of service is not quality and consumers do not feel satisfaction with the services provided by the company. Positive values are found in the tangibles, assurance and empathy variables which show that the service provided can be said to be a surprise and consumers feel satisfaction with the service.

\section{CONCLUSION}

Based on the results of the SerQual analysis there are 17 service attributes that affect the increase in customer satisfaction with services that are grouped into the Servqual dimension, namely:

a. Tangibles which has supporting physical facilities such as a comfortable service room and ample parking space, availability of spearparts, the appearance of staff and employees are tidy, and cleanliness of the machine after repair.

b. Reliability, namely speed and timeliness in providing services, seriousness and reliability of technicians in completing repairs, as well as the availability of historical data / recording systems that are good at service.

c. Responsiveness is providing services in accordance with the promise, providing a good explanation of repairs, costs and estimated time to consumers, as well as readiness in providing assistance to consumers if experiencing difficulties.

d. Assurance, namely the ability of service advisors in diagnosing problems / customer complaints, courtesy and friendliness of staff, providing guarantees and controlling with customers to be repaired 
e. Empathy is following up after the improvement, giving input and

\section{Referensi}

1. Arikunto, 2010. Prosedur Penelitian Suatu Pendekatan Praktik, Penerbit Renika Cipta, Jakarta

2. Chen, KeeKuo., Chang, ChingTer., Lai, ChengSheng. (2009) 'Service Quality Gaps of Business Customers In The Shipping Industry', TransportationResearch Part E 45, 222237

3. Hanafie, Hasim, 2011. RancanganPengendalianKualitasPelayan anDalamIndustriPerhotelanMenggunakan Pendekatan Quality Function Deployment, Tesis Program Studi Teknik Industri UI, Jakarta

4. Kotler, Philip And Kevin Lane Keller. 2012. Marketing Management 13, New Jersey: Pearson PresticeHall,Inc

5. Nasution, Arman Hakim 2006. ManajemenIndustri. Penerbit Andi Ofhset. Yogyakarta explanation to the customer, and providing accurate information.

6. Noor, Juliansyah,2011. Metodologi Penelitian, Skripsi Tesis, Desertasi Dan Karya Ilmiah . Penerbit : Kencana Prenada Media Group. Jakarta

7. Poniman 2016. UpayaPeningkatanPelayanan Jasa (Service Excellent) TerhadapKepuasanKonsumenMenggunak anPendekatanServqual Dan Quality Function Deployment (Qfd), Tesis Program Studi Teknik Industri ITATS, Surabaya

8. TjiptonoFandy, 2012. Service Management: MewujudkanLayanan Prima Edisi II. CV Andy Offset, Yogyakarta

9. Zeithaml Valerie A, M.J.Bitner, 2013, Sevice Marketing, First Edition,Usa:McGraw Hill Co.Inc 